\section{Childhood tuberculosis incidence in Southeast Brazil, 1996}

\author{
Incidência da tuberculose na infância \\ no Sudeste do Brasil, no ano de 1996
}

1 Serviço de Pediatria, Faculdade de Medicina de Taubaté, São Paulo, Brasil. 2 Faculdade de Medicina Universidade de São Paulo, São Paulo, Brasil.

Correspondence L. F. C. Nascimento Serviço de Pediatria, Faculdade de Medicina de Taubaté.

Av. Tiradentes 500 , Taubaté, $S P$

12080-130, Brasil. lfcn@feg.unesp.br lfcnascimento@uol.com.br

\begin{abstract}
This study aims to describe childhood tuberculosis incidence in Southeast Brazil in 1996. It is a descriptive study based on secondary records from the Tuberculosis Division of the São Paulo State Health Department. The study area includes 40 cities, has some 1,800,000 inhabitants, and is located between São Paulo and Rio de Janeiro, the largest cities in Brazil. The study included cases up to 15 years of age. Independent variables were: sex, age, type of case, clinical presentation, radiology, AFB microscopy, HIV antibody tests, and method of discovery. The incidence rate in this age bracket was 10.4/100,000. Pulmonary manifestations were the most common, and control of contacts was the most common method of case discovery. AFB microscopy was performed in $18.6 \%$ of the cases and HIV testing was done in 14.9\%. Incidence in this study was higher than for the State of São Paulo as a whole. Poor socioeconomic level, deterioration of public health services, treatment dropout by adults and their persistence as sputum-positive carriers, and flaws in case reporting and follow-up could explain these results.
\end{abstract}

Tuberculosis; Incidence; Child Health

\section{Introduction}

Tuberculosis is an important cause of morbidity and mortality among children around the world. Childhood tuberculosis is the result of recent infection and especially at younger ages reflects continuing transmission in the community.

The tuberculosis incidence rate remains unchanged in several developing countries, while in developed countries it has decreased due to the introduction of tuberculostatic drugs, improved socioeconomic conditions, and BCG vaccination.

In Asia and Africa, the incidence rate is approximately 220 cases/100,000 inhabitants, with pediatric cases representing some $15.0 \%$ of the total 1 .

In Brazil, tuberculosis incidence rates were $60.7 / 100,000$ overall, 11.3/100,000 in children below 5 years old age, and 5.8/100,000 in children from 5 to 9 years of age. In absolute numbers, there were 1,844 new cases up to 5 years old and 955 new cases in the 5-9-year bracket, with these two groups representing $2.7 \%$ of all cases in 2000 (http:/ / www.tabnet.datasus.gov. br/cgi/tabcgi.exe?idb2001/d0202.def, accessed on 10/Dec/2003).

Alves et al. 2 found an incidence rate of 27/ 100,000 in an analysis of reported cases of pediatric tuberculosis in Rio de Janeiro from 1989 to 1993. Incidence for all age groups in 1993 was $151 / 100,000$. 
Overall tuberculosis incidence in São Paulo State in 1996 was 51/100,000, with approximately $4.0 \%$ of cases occurring in childhood, predominantly the pulmonary and lymphnode clinical forms (http://www.cve.saude.sp. gov.br/htm/Tb_coef8099.htm, accessed on 18/ Jul/2002). In Brazil, there are few recent studies on tuberculosis incidence in this age group 2,3 .

Although tuberculosis is a disease of compulsory notification and the State Health Departments keep records from all the cities, the records are rarely analyzed and fail to provide accurate information on the tuberculosis profile in various States. The aim of this paper is thus to analyze incident cases of pediatric tuberculosis in the Paraiba Valley in São Paulo State for the year 1996.

\section{Methods}

This was a descriptive study using secondary data obtained from the Tuberculosis Division of the São Paulo State Health Department. The data are for reported cases from the Paraiba Valley, a region that comprises 40 cities with a total population of approximately 1.8 million. The Paraiba Valley is located between São Paulo and Rio de Janeiro, the two largest cities in Brazil. The study included cases up to 15 years of age.

The study variables were sex; age in years and grouped in the of 0-4, 5-9, and 10-15-year brackets; clinical presentation as pulmonary, lymph-node, pleural, and other non-pulmonary forms including meningeal, miliary, genitourinary, bone, ophthalmic, and diffuse; method of discovery; radiology; AFB microscopy; and HIV antibody test results.

These variables are included in the TB Notification Forms of the São Paulo State Health Department, Tuberculosis Division.

Table 1 shows the study variables and their respective percentages.

\section{Results and discussion}

A total of 1,410 new cases of tuberculosis were reported in 1996, representing an incidence rate of 78.3/100,000 inhabitants. These included 188 children up to 15 years of age. This portion represents $13.3 \%$ of all new cases reported in 1996. The incidence rate for children was $10.4 / 100,000$.

Overall tuberculosis incidence in the Paraiba Valley in 1996 was greater than that of São Paulo State as a whole (http://www.cve.saude.
Table 1

Quantitative values of variables with respective percentages.

\begin{tabular}{|c|c|}
\hline Variables & $\begin{array}{l}\text { Number of } \\
\text { cases }^{\star}(\%)\end{array}$ \\
\hline \multicolumn{2}{|l|}{ Age (years) } \\
\hline Below 5 & $74(39.4)$ \\
\hline $5-9$ & $60(31.9)$ \\
\hline $10-15$ & $54(28.7)$ \\
\hline \multicolumn{2}{|l|}{ Method of discovery } \\
\hline Contact search & $83(44.1)$ \\
\hline $\begin{array}{l}\text { Spontaneous medical visit } \\
\text { with respiratory symptoms }\end{array}$ & $53(28.2)$ \\
\hline Suspected tuberculosis & $46(24.5)$ \\
\hline Presentation with other causes & $6(3.2)$ \\
\hline \multicolumn{2}{|l|}{ Clinical forms } \\
\hline $\begin{array}{l}\text { Pulmonary (AFB+, AFB-, } \\
\text { and AFB not performed) }\end{array}$ & $178(94.7)$ \\
\hline Peripheral lymph nodes & $3(1.6)$ \\
\hline Pleural & $1(0.5)$ \\
\hline Others & $3(1.6)$ \\
\hline No information & $3(1.6)$ \\
\hline \multicolumn{2}{|l|}{ X-ray results } \\
\hline Suspected tuberculosis & $142(75.5)$ \\
\hline Normal & $7(3.7)$ \\
\hline With cavities & $3(1.6)$ \\
\hline Not performed & $3(1.6)$ \\
\hline No information & $33(17.6)$ \\
\hline \multicolumn{2}{|l|}{ HIV antibody test results } \\
\hline Positive & $8(4.3)$ \\
\hline Negative & $20(10.6)$ \\
\hline Not performed & $160(85.1)$ \\
\hline \multicolumn{2}{|l|}{ AFB in sputum } \\
\hline Positive & $10(5.3)$ \\
\hline Negative & $25(13.3)$ \\
\hline Not performed & $153(81.4)$ \\
\hline \multicolumn{2}{|l|}{ Sex } \\
\hline Male & $89(47.3)$ \\
\hline Female & $99(52.7)$ \\
\hline
\end{tabular}

Total $=188$ cases.

AFB $=$ acid-fast bacillus. 
sp.gov.br/htm/Tb_coef8099.htm, accessed on 18/Jul/2002). The particular year was selected because the records had been consolidated by the Tuberculosis Division of the São Paulo State Health Department, so there was little probability of bias.

As for childhood tuberculosis, the values found in this study are below those reported by Alves et al. 2 , and the case proportion was higher than reported by Oliveira et al. 3 in Rio de Janeiro in 1993 (6.6\%), who considered children up to 14 years of age. However, the inclusion of children up to 15 years old (that is, an additional year) in our study was unlikely to have caused this large increase to $13.3 \%$. The Brazilian records as a whole showed proportions of around $7.0 \%$ in 1993.

In the $\leq 9$-year bracket, our findings were higher than the Brazilian national statistics (9.5\% vs. $2.7 \%$ ) (http://www.tabnet.datasus. gov.br/cgi/tabcgi.exe?idb2001/d0202.def, accessed on 10/Dec/2003). Chaimowicz 4 showed an incidence of 11.2/100,000 inhabitants in the year 1996 in the 0-9-year age bracket, which was higher than the 7.4/100,000 incidence found in our study in the same age group.

However, the incidence found in our study is higher than that of England 5. In Cuba, tuberculosis incidence is approximately 5 cases / 100,000 inhabitants 6, and in Qatar the incidence is 7 cases $/ 100,000$ inhabitants 7 .

Our age distribution agrees with data presented in other studies $2,3,4$, with a predominance of children under 5 years old. The most frequent clinical presentation was the pulmonary form, with a proportion higher than that of Rio de Janeiro State and Brazil as a whole 3 . There was one case of the meningeal form, with no information concerning the child's vaccination status. This low incidence of the meningeal form may be due to higher BCG vaccination coverage (http://www.cve. saude.sp.gov.br/htm/imu_sh.htm, accessed on 10/Mar/2003).

The most common method of discovery for new pediatric cases was through contact searches, since childhood tuberculosis is related to recent infection from a sputum-positive carrier.

The large number of spontaneous medical visits involving children with respiratory symptoms could be explained by a public campaign that associated respiratory signs with the possibility of tuberculosis.

Radiological examination was abnormal in $77.0 \%$ of all cases, and cavities were present in $1.6 \%$. There was no information in $18.0 \%$, a figure higher than that described by Oliveira e al. ${ }^{3}$, and this fact lacks a convincing explanation.
This fact, plus the ease of performing radiological examination, highlights the importance of such imaging support.

AFB microscopy was performed in 35 cases (18.6\%) and was positive in 10 cases, with negative results in 25 . Childhood tuberculosis presents few bacilli, and children tend to be incapable of coughing up sputum. The figures refer to sputum results, since the gastric wash technique is a more complex procedure and is routinely used in outpatient care. The findings from this paper are lower than those of Oliveira et al. 3 .

HIV antibody testing was performed in 28 cases (14.9\%) and was positive in 8; it was not performed in 160 cases $(85.1 \%)$. These values are consistent with those of Oliveira et al. ${ }^{3}$. It is recommended that the proportion of HIV antibody testing be increased, because of the association between tuberculosis and AIDS.

Lower socioeconomic status, treatment dropout with maintenance of the bacilli source, faulty case reporting and follow-up, and finally the deterioration of health services could explain the findings in this study. Nevertheless, it was beyond the scope of this study to determine the causes of the findings or to comment on health policy in tuberculosis care.

It is important to note that there are few studies on childhood tuberculosis incidence in Brazil, despite the large volume of collected data in the various State Health Departments. The fact that this study was based on secondary records could be a potential limitation; still, we observed only a $1.6 \%$ error rate in classification of clinical forms on the Tuberculosis Notification sheets.

Our study thus showed a pediatric tuberculosis incidence rate in the Paraiba Valley for the year 1996 that was higher than the State of São Paulo as a whole, with a predominance of the pulmonary clinical form. In addition, there was a low rate of HIV antibody testing in cases. These findings are consistent with those of other studies $2,3,4,8$.

Use of secondary records from official data files can be useful for determining the incidence of diseases such as tuberculosis, and this technique should be encouraged.

The most recent data on tuberculosis in the São Paulo State Health Department (Tuberculosis Division) are from the year 1999, so these records are more up-to-date and can supply information on the tuberculosis situation so as to help evaluate the respective health policies. 


\section{Resumo}

O objetivo deste estudo é descrever a incidência de tuberculose na infância, no Sudeste do Brasil. Trata-se de um estudo descritivo, com dados secundários obtidos junto à Divisão de Tuberculose da Secretaria Estadual de Saúde de São Paulo, relativos ao ano de 1996. A região estudada é composta por quarenta municípios, com população estimada em 1.800.000 habitantes e localizada entre São Paulo e Rio de Janeiro. As variáveis estudadas foram: sexo, idade, tipo de caso, forma clínica, tipo de descoberta e resultados dos exames radiológicos, de baciloscopia e do teste anti-HIV. Foram incluídos pacientes com até 15 anos de idade. A incidência de tuberculose encontrada nesta faixa etária foi de 10,4/100 mil habitantes. A forma pulmonar foi a mais freqüentemente encontrada e o tipo de descoberta de casos novos mais importante foi por meio de busca de comunicantes. A pesquisa de BK no escarro foi realizada em 18,6\% dos casos e o teste antiHIV, em 14,9\%. A incidência encontrada neste estudo está acima da do Estado de São Paulo. As possíveis causas seriam piora da situação sócio-econômica, piora dos serviços de saúde, abandono do tratamento por parte do adulto bacilífero e falhas na notificação e no seguimento dos doentes.

Tuberculose; Incidência; Saúde Infantil

\section{References}

1. Murray CJL, Styblo K, Rouillon A. Tuberculosis in developing countries: burden, intervention, and costs. Bull Int Union Tuberc Lung Dis 1990; 65:6-24.

2. Alves R, Sant'Anna CC, Cunha AJLA. Epidemiologia da tuberculose infantil na cidade do Rio de Janeiro, RJ. Rev Saúde Pública 2000; 34:409-10.

3. Oliveira HMV, Ruffino Neto A, Vasconcellos GS, Dias SMO. Situação epidemiológica da tuberculose infantil no Município do Rio de Janeiro. Cad Saúde Pública 1996; 12:507-13.

4. Chaimowicz F. Age transition of tuberculosis incidence and mortality in Brazil. Rev Saúde Pública 2001; 35:81-7.

5. Parslow R, El-Shimy NA, Cundall DB, McKinney PA. Tuberculosis, deprivation, and ethnicity in Leeds, UK, 1982-1997. Arch Dis Child 2001; 84: 109-13.

6. Borroto-Gutierrez S, Armas-Perez L, GonzalesOchoa E, Pelaéz-Sanchez O, Arteaga-Yero AL. Distribución y tendencia de la tuberculosis por grupos de edades y por municipios en Ciudad de la Habana, Cuba (1986-1998). Rev Esp Salud Publica $2000 ; 74: 507-15$.

7. Al-Marri MR. Childhood tuberculosis in the State of Qatar: the effect of a limited expatriate screening programme on the incidence of tuberculosis. Int J Tuberc Lung Dis 2001; 5:831-7.

8. Dye C, Scheele S, Dolin P, Pathania V, Raviglione MC. Consensus statement: global burden of tuberculosis, estimated incidence, prevalence and mortality by country. JAMA 1999; 282:677-86

Submitted on 07/Apr/2003

Final version resubmitted on 19/Dec/2003

Approved on 29/Apr/2004 